\title{
Kendala-Kendala Pendeteksian Praktik Insider Trading dalam Transaksi Saham di Bursa Efek
}

\author{
Ridwan Khairandy
}

\begin{abstract}
Before the investor made his decision rationally for purchasing or buying the stock exchange in general, he examines first the condition of company involved. That is why, the transparency principle is the most important matter in transaction in stock exchange. Although, carrying out the transparency principles are sometimes create the handicaps through insider trading practices and it is sometimes difficult to be solve with law perspective. The difficulties are caused by the weak of law instrument and the borderless about when public are be able to show the fact materially and openly.
\end{abstract}

\section{Pendaḥuluan}

Prinsip keterbukaan (disclosure principle) menjadi persoalan inti di pasar modal dan sekaligus merupakan jiwa pasar modal itu sendiri. Dengan keterbukaan tersebut, tersedianya informasi bagi investòr, sehingga dapat diambil keputusan rasional untuk membeli atau menjual efek.'

Salah satu bentuk pelanggaran prinsip keterbukaan tersebut adalah insider trading. Insider trading sering terjadi dalam transaksi efek dibursa efek, tetapi seringkali dipertanyakan mengapa praktik insider trading sulit diselesaikan secara hukum. Ada kesulitan dalam pembuktian terjadinya praktik insider trading.

\section{Subjek Insider trading}

UU No. 8 Tahun 1995 tentang Pasar Modal tidak memberikan definisi insider trading secara tegas. Undang-undang tersebut hanya memberikan batasan terhadap transaksi-transaksi yang dilarang antara lain yang dilakukan oleh orang dalam dari emiten yang memiliki informasi orang dalam dilarang melakukan transaksi penjualan atau pembelian efek emiten atau perusahaan lain yang melakukan transaksi dengan emiten atau perusahaan publik yang bersangkutan. ${ }^{2}$

Penjelasan Pasal 95 UUPM mengkategorikan orang dalam sebagai

'Bismar Nasution, Keterbukaan dalam Pasar Modal (Jakarta: Program Pascasarjana Fakultas Hukum Universitas Indonesia, 2001), hlm. 1.

2 Ridwan Khairandy dan Najib, "Aspek Hukum Insider Trading di Bursa Efek", Media Advokat, Edisi Perdana 1997, hlm. 23. 
berikut:

1. Komisaris, direktur, atau pegawai perusahaan terbuka;

2. Pemegang saham utama perusahaan terbuka;

3. Orang yang karena kedudukannya, profesinya, atau karena hubungan usahanya dengan perusahan terbuka memungkinkan memperoleh informasi orang dalam. Dengan kedudukan di sini dimaksudkan sebagai lembaga, institusi, atau badan pemerintahan. Sementara yang merupakan hubungan usaha adalah hubungan kerja atau kemitraan dalam kegiatan usahanya, seperti nasabah, pemasok, kontraktor, kreditur dan lain-lain.

4. Pihak yang tidak lain menjadi pihak sebagaimana tersebut dalam poin 1,2 , dan 3 tersebut sebelum lewat jangka waktu 6 bulan.

Menurut Pasal 95, 96, dan 97 UUPM yang termasuk trading yang dilarang adalah: ${ }^{3}$

1. Orang dalam yang melakukan pembelian atau penjualan atas ;

a. efek perusahaan dimana informasi berasal;

b. efek perusahaan lain yang melakukan transaksi dengan perusahaan transaksi tersebut.

2. Orang dalam yang mempengaruhi pihak lain untuk melakukan pembelian atau penjualan atas efek tersebut.

3. Orang dalam yang memberi informasi orang dalam kepada pihak lain manapun yang patut diduga dapat menggunakan informasi tersebut melakukan pembelian atau penjualan efek.

4. Orang lain yang secara melawan hukum memperoleh informasi orang dalam dari orang dalam tersebut lalu digunakannya dengan cara-cara seperti tersebut dalam butir 1,2 dan 3 tersebut.

5. Orang lain yang berusaha untuk memperoleh informasi orang dalam secara tidak melawan hukum, tetapi penyediaan informasi tersebut dengan pembatasan-pembatasan (misalnya dengan kewajiban merahasiakan), kemudian menggunakan informasi tersebut dengan cara-cara seperti dimaksud dalam butir 1, 2 dan 3 tersebut.

6. Perusahaan efek yang memiliki informasi orang dalam dari suatu perusahaan terbuka yang melakukan transaksi seperti dimaksud dalam butir 1,2 dan 3 tersebut, kecuali yang terpenuhi dua syarat sebagai berikut :

a. Transaksi dilakukan bukan atas. tanggungan sendiri, tetapi atas perintah nasabah, dan

b. Perusahaan efek tersebut tidak memberikan rekomendasi kepada nasabahnya mengenai efek yang bersangkutan.

Sebenarnya masih ada pihak lain selain yang disebut dalam UUPM yang mestinya masih mungkin dan pantas dijerat dengan perbuatan insider trading ini. Pihak lain itu adalah pihak yang menerima informasi dari insider (tidak secara malawan hukum) yang masih belum masuk kategori persyaratan "dengan pembatasan" sebagaimana dimaksud

${ }^{3}$ Munir Fuady, Pasar Modal Modem (Bandung: Citra Aditya Bakti, 1996), hlm. 171. 
butir 5 di atas (Pasal 97 ayat (2) UUPM). Bahkan, mungkin hanya pasif saja dalam menerima informasi tersebut tetapi kemudian digunakan dalam artian trading UUPM menggunakan kata-kata "berusaha untuk memperoleh informasi" bagi pihak lain, yang berarti pinak lain tersebut harus aktif dan inisiatif untuk mendapatkan informasi tersebut mesti berasal dari pihak lain tersebut. Misalnya apa yang disebut sebagai tippee, baik yang aktif. mencari informasi, ataupun yang pasif menerima informasi tanpa mencarinya. Mestinya pihak tippee ini dilarang juga untuk melakukan trading dalam pengertian insider trading. Sementara yang dilarang UUPM hanyalah pihak tippee yang aktif dan dengan inisiatifnya sendiri mencari informasi, dimana: ${ }^{4}$

1. Informasi tersebut dicari dengan jalan melanggar hukum, seperti dengan mencuri membujuk, kekerasan, atau ancaman atau;

2. Atas informasi tersebut disertai dengan pembatasan-pembatasan (seperti kewajiban merahasiakan).

Bahkan semestinya, selain tippee tersebut (aktif atau pasif), apa yang disebut secondary tippee pun pantas dilarang. Secondary tippee adalah pihak lain yang menerima informasi bukan langsung dari orang dalam tetapi melalui tippee yang lain.

Selain itu, pihak-pihak seperti konsultan hukum pasar modal, akuntan publik, penilai (appraiser), notaris, dan investment bankers juga terikat untuk tidak melakukan trading untuk saham dari emiten yang bersangkutan, berdasarkan teori yang dikenal dengan sebutan contractual obligation of confidentiality. Mestinya pihak-pihak yang pantas dikecualikan sebagai insider adalah : 5

1. Analis yang independen, seperti orang luar yang ahli dalam bidang tertentu, di mana dengan keahliannya dapat memperkirakan dengan tepat tentang apa yang terjadi dalam perusahaan, atau;

2. Penerima informasi secara kebetulan, seperti seseorang yang kebetulan "nguping" percakapan di antara dua orang di sebuah warung pojok.

Beberapa kasus melonjaknya harga suatu saham di lantai bursa banyak yang berbau insider information. Artinya, pembelian atau penjualan saham tersebut terjadi setelah ada informasi dari "orang dalam". Hal tersebut antara lain dijelaskan dalam beberapa kasus di bawah ini.

\section{Kasus Saham Super Mitory Utama ${ }^{6}$}

Indikasi insider trading lainnya dapat dilihat dari transaksi saham Super Mitory Utama, tanpa adanya informasi yang sifatnya materiel, saham Super Mitory Utama secara tiba-tiba transaksinya melejit sampai 64,71 persen. Pada awal transaksi tanggal 14 Maret 1996 harga sahamnya menjadi Rp. 850,00 dan pada akhir sesi kedua ditutup harga sahamnya menjadi Rp. 1.400. Dua bulan kemudian tangal 14 Mei 1996 terdapat berita bahwa PT Super Mitory Kencana menguasai saham Super

\footnotetext{
4 Ibid, hlm. 172.

${ }^{5} /$ bid, hlm. 173.

${ }^{6}$ Bismar Nasution, op.cit, hlm. 184.
} 
Mitory Utama. Di samping indikasi-indikasi ini, terdapat juga tudingan terjadinya insider trading sebagaimana diarahkan kepada TFT saat transaksi saham PT. Elang Realty (ELTY). la dituding memborong saham ELTY tanggal 26 - 28 Februari 1997 berdasarkan informasi orang dalam dan melepas kembali saham tersebut saat harganya naik. Terhadap kasus ini Badan Pengawas Pasar Modal (Bapepam) masih melakukan penelitian dan Bapepam menyatakan bahwa insider trading tidak mudah dibuktika. Dua bulan kemudian, tepatnya tanggal 14 Mei 1996 muncul berita bahwa PT. Surya Mitory Kencana akan menguasai $48,6 \%$ saham Super Mitory Utama, setelah membeli 9, 803 juta lembar saham PT. Gita. Pacific.

\section{Kasus Perdagangan PT Saham Semen Gresik Tbk ${ }^{7}$}

Indikasi terjadinya insider trading juga dapat dicermati dari perdagangan saham PT Semen Gresik Tbk. Pada tanggal 14 Maret 1996 harga saham SG tiba-tiba melejit $64,71 \%$ dalam satu hari transaksi. Dari posisi awal sesi pertama harga sahamnya Rp. 850 mengalami kenaikan yang bergerak terus hingga penutupan sesi kedua dengan ditutup pada posisi Rp 1. 400,00 .

Perdagangan saham PT Semen Gresik Tbk disebut berindikasi insider trading berawal dari pernyataan bekas ketua Bapepam I Putu Gede Ary Suta pada tanggal 22 Juni 1998 beberapa saat sebelum ia diganti sebagai ketua Bapepam. Bapepam mensinyalir adanya kasus insider trading dalam perdagangan saham Semen Gresik. Bahkan, pengamat pasar modal juga menduga telah terjadi praktik insider trading dalam perdagangan saham PT Semen Gresik Tbk.

Munculnya indikasi insider trading dalam perdagangan saham ini bermula dari pengungkapan secara tajam harga saham PT Semen Gresik Tbk. Peningkatan harga saham ini dianggap tidak wajar, disebabkan dalam jangka waktu 2 minggu harganya melonjak $60 \%$. Hal ini misalnya dapat dilihat pada 3 Juni harganya tercatat $\mathrm{Rp} .4 .850,00$ dan hari berikutnya pada 16 Juni meningkat dengan tajam menjadi Rp. 7.800,00 bahkan sempat menyentuh Rp. $10.000,00$. Volume perdagangan saham pada tanggal 3 Juni 1998 tercatat 977.500 lembar dengan nilai, perdagangan Rp. 4.772.500.000,00 dan tanggal 16 Juni 1998 volumenya 2.193 .500 lembar dengan nilai perdagangan Rp. 16.846 .937 .500 yang paling menonjol perdagangan ini dapat dilihat pada tanggal 19 Juni 1998.

Kenaikan harga saham ini seiring dengan rencana privatisasi BUMN termasuk PT Seman Gresik Tbk atau divestasi 65 persen saham PT Semen Gresik Tbk. Tanggal 19 Juni 1998, setelah Rapat Umum Pemegang Saham (RUPS) menerima penawaran dari calon mitra strategis, yang terdiri dari Mexico (Cement Mexico), Swiss (Holderbank) dan Jerman (Zemeut AG). Pada 18 Juni 1998 tiga dari lima belas perusahaan sekuritas yang sangat menonjol melakukan perdagangan saham adalah PT. Danareksa Securities, PT. Bahana Securities dan Jardine Fleming Nusantara.

\footnotetext{
${ }^{7}$ lbid, hlm 185.
} 
Indikasi insider trading tersebut sampai sekarang ini belum dapat dituntaskan. Tidak tuntasnya kasus-kasus tersebut, disamping alasan sulitnya pembuktian kasus insider trading, juga tidak cukupnya formulasi peraturan insider trading di pasar modal Indonesia. ${ }^{B}$

Sebenarnya soal kasus ini, bila dilihat secara materi, bukan hal yang terlalu biasa, karena soal dugaan adanya insider trading disetiap kebocoran atau keanehan pergerakan saham di lantai bursa, sering diteriakan oleh investor. Dugaan-dugaan tidak pernah terselesaikan secara tuntas. "Ributnya" soal insider trading di PT Semen Gresik Tbk, dipicu oleh faktor-faktor sebagai berikut :9

1) Pernyataan tentang dugaan adanya insider trading disampaikan oleh seorang ketua Bapepam yang secara fungsional saat itu meimegang kendali organisasi;

2) Saham yang diduga menjadi ajang "perselingkuhan", kebetulan adalah saham perusahaan milik pemerintah yang sedang dalam proses privatisasi, dan volume transaksi serta lalu lintas perdagangan di saham tersebut tergolong aktif dan mendapat banyak perhatian;

3) Kemudian pihak-pihak yang diduga terlibat, baik itu pialang maupun individuindividunya adalah mereka yang memiliki posisi penting dalam proses dan pengambilan keputusan tentang rencana privatisasi tersebut;

4) Pada saat yang bersamaan puia, ganjalan privatisasi PT Semen Gresik Tbk, tidak hanya datang dari lantai bursa tetapi juga

${ }^{8}$ Ridwan Khairandy dan Najib, op.cit, hlm. 31.

${ }^{8} \mathrm{http}: / / \mathrm{www}$. Bapepam. go.id.

${ }^{10}$ Indra Safitri, Transparansi Independensi dan Kejahatan Pasar Modal (Jakarta: Go Global Book, 1998), him. 229. berbagai protes dan masalah kepentingan lainnya, yang berurutan dengan polemikpolemik seputar PT Krakatau Steel Tbk dan PT Telkom Tbk;

5) Pada kondisi awal perbincangan soal insider trading, Bapepam terlihat tidak menunjukkan sikap yang independen, namun ada kesan mengambil posisi aman untuk diam, justru yang menyatakan soal kemungkinan-kemungkinan tersebut datangnya dari kantor Menteri Negara BUMN.

Jadi terlihat adanya benturan-benturan kepentingan, kekuasaan dan kekuatan, sehingga persoalan insider trading itu tidak dibahas dan dikaji secara jernih dalam konteks dan hubungan hukum. Sebaliknya, terlihat kesan ada pertarungan elit politik soal masalah itu. Jadi jangan heran di dalam kasus ini ada nuansa-nuansa politik yang tidak dapat dilepaskan begitu saja. Justru hal semacam ini tidak memberikan kondisi yang kondusif untuk mengembangkan perangkat hukum sebagai alat untuk mencegah timbulnya praktik kotor dan curang sehingga membuat semakin jauh larinya para investor yang merasa tidak adanya perlindungan dan keamanan soa! investasi.

Indikator terjadinya insider trading biasanya tercium ketika pelaku telah melakukan penjualan atas saham yang dibelinya, dengan menggunakan informasi orang dalam jumlah yang signifikan adalah faktor pemicu yang dapat mengarahkan para penyidik pada dugaan telah dilakukannya pelanggaran tersebut. ${ }^{10}$ 
Secara tekhnis, penggunaan variabel transaksi yang dilakukan melalui perusahaan efek, yang berkepentingan dalam transaksi tersebut, dapat dijadikan sebagai alat untuk melacak. Hal ini penting, karena menyangkut pengerahan harga dan jumlah transaksi yang terjadi sebelum dan sesudah informasi diterima oleh pasar. Oleh sebab itu, sistem pengawasan pasar harus segera bereaksi bila variabel dan pola insidertrading terjadi di salah satu counter saham emiten."

\section{Pendeteksian Insider trading}

Amerika Serikat mengembangkan dua metode pendeteksian praktik insider trading secara dini, yakni surveillance dan bounties ${ }^{12}$

\section{Surveillance (Pengawasan)}

Metode yang dipergunakan adalah melakukan penelitian (pemeriksaan) ke belakang dari bukti perdagangan efek yang tidak sah secara tidak langsung. Alat pengawasan pasar. secara elektronik adalah sangat mudah untuk dapat mengetahui secara cepat volume perdagangan, sehingga dapat menyimpulkan secara kuat atau pasti bahwa seseorang telah melakukan perdagangan, berdasarkan pengetahuan informasi yang berharga atau sensitive.

Business Week misalnya, telah melaporkan dalam artikelnya mengenai penyelidikan yang dilakukan oleh Pasific Stock Exchange dan SEC terhadap perdagangan call option pada saham Amerika Broadcasting Company. Pada minggu sebelum diumumkannya akuisisi oleh Capital Cities Communication Inc. Harga saham naik sampai $42 \%$, kenaikan harga tersebut luar biasa baik dalam volume perdagangan maupun harga berbagai macam $A B C$ call option. Sementara itu tidak seorangpun dari yang membeli call option tersebut mengetahui adanya informasi mengenai merger, aktivitas perdagangan tersebut sebenarnya tidak dapat dijelaskan sampai terjadinya insider trading.

The New York Exchange misalnya, mempunyai Stock Watch Group, yang mana keduanya terus menerus mencatat aktivitas perdagangan melalui komputer pengawas setiap hari dan mengadakan penyelidikan ketika terdapat informasi yang mencurigakan. Pada tahun 1985, Group menyampaikan adanya 6000 kasus yang mungkin menyimpanig dan mengadakan penyelidikan terhadap $10 \%$ dari kasus tersebut, dan akhimya menemukan kemungkinan diadakannya penyelidikan secara formal dalam $10 \%$ kasus tersebut.

Penyelidikan secara formal yang dilakukan bukan tidak mungkin akan berhasil. Wall Street Journal dalam salah satu artikelnya, memperkirakan proses penegakan hanya $15 \%-20 \%$ dari penyelidikan yang dilakukan dapat berhasil.

\section{Bounties (Hadiah)}

Konggres Amerika pada pembuatan undang-undang baru tentang insider trading menambahkan keuntungan agar Stock Exchange Commission (SEC) atau Departemen Kehakiman memberikan penghargaan

\footnotetext{
"lbid.

${ }^{12}$ Najib A. Gisymar, Insidertrading dalam Transaksi Efek (Bandung: Citra Aditya Bakti, 1999), hlm. 48-50.
} 
kepada seseorang atau beberapa orang yang memberikan informasi, yang pembayarannya dibebankan dari $10 \%$ hukuman atau denda dari pelakunya. Ketentuann baru sebagaimana terdapat dalam Pasal 21A (e) Securities Exchange Act of 1984, merupakan suatu kebulatan tekad yang dilakukan semata-mata merupakan kebijakan administratif dan bukan persoalan pokok pada judicial review. Bagaimanapun juga, maksud pemberian hadiah tersebut kepada karyawan perusahaan sekuritas merupakan perkecualian dan bukan merupakan suatu peraturan.

Jepang mengadakan beberapa pengembangan peraturan mengenai insider trading. Hal tersebut dilakukan karena adanya kecenderungan internasional yang mengawasi secara teliti terhadap insider trading. The Securities Dealer Association of Japan melakukan adopsi beberapa ketentuan baru dalam praktik yang fair, yaitu: ${ }^{13}$

1. Seseorang sebagai anggota perusahaan harus mencoba untuk mencegah pegawai atau pemegang saham utama perusahaan dari penjualan atau perusahaan saham dengan mempergunakan informasi khusus karena posisinya;

2. Anggota perusahaan harus mempunyai peraturan didalam perusahaannya yang melawan insider trading dan memastikan atau menjamin karyawannya mengikutinya;

3. Perusahaan sekuritas diwajibkan mengadakan sistem kartu baru, yang mana kartu tersebut dapat mengklasifikasikan orang dalam seperti direktur perusahaan, suami atau istrinya, dan famili, pemegang saham

\section{${ }^{13} \mathrm{Ibid}$.}

${ }^{14}$ Pasal 85 ayat (1) Jo. Pasal 98 ayat (1) Undang-undang Perseroan Terbatas (UUPT).

${ }^{15}$ Pasal 102 ayat (3) UUPT. utama, afiliasi perusahaan dan lain-lain serta memperlihatkannya pada kartu informasi. Staf perusahaan diharapkan mempergunakan sistem tersebut dalam mencegah insider trading.

Pencegahan praktik insider trading di Indonesia dilakukan dengan cara menegakkan secara tegas ketentuan yang tercantum dalam Undang-undang Pasar Modal dan Undangundang Perseroan Terbatas. Kedua Undangundang tersebut diharapkan dapat mengantisipasi praktik insider trading, meskipun sampai saat ini belum dipergunakan secara maksimal.

Undang-undang Pasar Modal secara tidak langsung menganut fiduciary duty theory. Hal tersebut dapat terlihat dengan jelas pada ketentuan Pasal 95 Undang-undang Pasar Modal mengenai batasan orang dalam. Berdasarkan hal tersebut, maka apabila terjadi praktik insider trading dalam arti breach of $\mathrm{fi}$ duciary duty, pencegahan atau pertanggungjawabannya dapat dilakukan, tetapi di luar hal tersebut; pencegahannya sulit sekali sebagaimana kasus di Amerika Serikat.

Undang-undang Perseroan Terbatas memberikan amanat yang besar bagi para direksi dan komisaris dalam menjalankan serta mengawasi perseroan. Setiap anggota direksi maupun komisaris wajib dengan iktikad baik dan penuh tanggung jawab menjalankan tugasnya untuk kepentingan dan usaha perseroan. ${ }^{14}$ Apabila perseroan akan melakukan merger, akuisisi maupun konsolidasi, maka harus mendapatkan persetujuan dari Rapat Umum Pemegang Saham masing-masing perseroan. ${ }^{15}$ 
Rencana perseroan yang telah "go public untuk melakukan merger, akuisisi maupun konsolidasi merupakan suatu fakta materiel yang harus dibuka kepada masyarakat atau investor. Fakta tersebut sangat menentukan terjadinya fluktuasi harga perseroan yang bersangkutan. Pelanggaran terhadap ketentuan tersebut, maka pihak perseroan akan terkena sanksi sebagaimana diatur dalam Pasal 104 Undang-undang Pasar Modal.

Pemegang saham perseroan meminta pertanggungjawaban direksi terhadap fakta materiel yanig ada, tetapi tidak dibuka kepada masyarakat. Dengain kata lain, informasi materiel yang belum terbuka tersebut hanya dipergunakan untuk kepentingan pribadi direksi. Atas nama perseroan, pemegang saham yang mewakili paling sedikit $1 / 10$ (satu persepuluh) bagian dari jumlah seluruh saham. dengan hak suara yang sah dapat mengajukan gugatan ke Pengadilan Negeri terhadap anggota direksi atau komisaris yang karena kesalahan atau kelalaiannya menimbulkan kerugian pada perseroan. ${ }^{16}$

Praktik insider trading jelas merupakan pelanggaran terhadap prinsip keterbukaan dalam perdagangan efek. Pengaturan terhadap larangan insider trading ditujukan untuk menciptakan mekanisme perdagangan efek yang efisien dan fair.

Di dalam praktik, penelusuran terhadap insider trading ternyata bukan suatu hal yang mudah, banyak sekali kesulitannya. Kesulitan tersebut antara lain disebabkan oleh Lemahnya pengaturan hukum dan tidak adanya batasan mengenai kapan örang dalam dapat melakukan transaksi setelah materiel terbuka:"

\section{Lemahnya Pengaturan Hukum}

Kasus-kasus insider trading yang terjadi di Amerika Serikat pada awalnya mengenai pelanggaran terhadap kewajiban menyampaikan informasi kepada masyarakat. Hal tersebut dapat dilihat dalam kasus Texas Gulf Sulphur Company dan Cady, Robert \& Co. Dalam perkembangan kasus berikutnya, Securities Exchange and Commission (SEC) dengan Securities Exchange Act of 1934. Mampu menjangkau setiap orang yang mempergunakan informasi yang belum terbuka bagi masyarakat untuk melakukan transaksi efek (misappropriation theory).

Pertimbangan yang dipergunakan teori tersebut bukan mengenai adanya larangan terhadap Fiduciary Duty, tetapi kepada persoalan adanya informasi yang diperoleh seseorang dan informasi tersebut disalahgunakan untuk melakukan transaksi efek.

Penjelasan Pasal 95 huruf a UUPM sepintas kelihatan cukup jelas. Tidak ada penafsiran yang berbeda bagi masyarakat mengenai komisaris dan direktur, tetapi bagaimana dengan status pegawai.

Penjelasan Pasal 95 huruf a di atas tidak menjelaskan lebih lanjut mengenai siapa yang dimaksud dengan pegawai emiten. Ketidakjelasan tersebut menimbulkan penafsiran yang berbeda, yaitu apakah pegawai emiten tersebut hanya ditujukan kepada

\footnotetext{
${ }^{10}$ Pasal 85 ayat (3) Jo. Pasal 98 ayat (2) UUPT.

${ }^{17}$ Ridwan Khairandy dan Najib A. Gisymar, op.cit, hlm. 31.
} 
pegawai tetap, ataukah juga terhadap pegawai tidak tetapnya. Apabila yang dimaksud pasal tersebut hanya pegawai tetapnya saja, maka UU tersebut tidak akan dapat menjangkau pegawai tidak tetapnya yang melakukan transaksi efek yang didasarkan pada fakta materiel yang belum terbuka untuk masyarakat yang diperoleh secara tidak sengaja, artinya diperoleh secara tidak langsung oleh orang dalam. ${ }^{18}$ UUPM juga masih mengandung celah hukum (loopehole) dalam menjangkau insider trading yang didasarkan penggunaan atau penyalahgunaan informasi oleh orang luar untuk melakukan transaksi. Undangundang hanya mampu menjangkau insider trading karena pelanggaran Fiduciary Duty.

Undang-undang dapat menjatuhkan sanksi bagi pemberi maupun penerima tip dari orang dalam mengenai fakta materiel. ${ }^{19}$ la tidak mampus menjangkau atau menjatuhkan sanksi terhadap seseorang yang bukan orang dalam yang mendapatkan informasi secara tidak sengaja, yaitu kebetulan mendengar pembicaraan orang dalam mengenai kebijakan perusahaan yang merupakan suatu fakta materiel, misalnya rencana akuisisi terhadap perusahaan target.

Berdasarkan informasi yang diperoleh tidak sengaja itu kemudian disampaikan kepada temannya lagi yang memahami transaksi efek, sehingga akhirnya mereka membeli saham perusahaan target yang dimaksud dalam jumlah yang signifikan.

Contoh lain dapat dikemukakan, yaitu kasus yang menimpa R. Foster Winan seorang wartawan The Wall Street Journal beserta temannya yang digugat karena menyalahgunakan informasi perusahaannya. R. Foster Winan dan temannya menulis (co author) kolom Heard of the Street di jurnal tersebut. ${ }^{20}$

Kolom tersebut adalah sejenis penilaian dan analisis mengenai kondisi perusahaan tertentu yang tercatat di Bursa Amerika Serikat. Penilaian dan analisa tersebut didukung hasil riset yang baik dari kedua penulis itu. Sehingga kolom itu sangat berwibawa dan diminati para pelaku bursa serta dapat mempengaruhi harga saham perusahaan yang bersangkutan. ${ }^{21}$

Keadaan tersebut dimanfaatkan keduanya untuk menambah penghasilan dengan cara memberitahukan hasil analisisnya kepada teman baiknya mengenai isi kolom yang belum beredar dengan menganjurkannya untuk melakukan transaksi atas dasar rekomendasi Winan. Winan beserta temannya memperoleh keuntungan ribuan dollar. ${ }^{22}$

Berdasarkan misappropriation theory, SEC menuduh Winan telah melakukan insider trading. Winan dianggap telah menyalahgunakan informasi Wall Street demi keuntungan pribadinya. SEC beranggapan juga, bahwa Winan mengetahui secara sadar kebijakan Wall Street dimana dia harus

${ }^{18}$ Sofyan A. Jalil, "Manipulation dan insider trading", makalah di Pendidikan dan Pelatihan bagiProfesi Penunjang untuk Konsultan Hukum Pasar Modal Angkatan VII, LMKA-BPLK, Jakarta, 21 )ktober -8 November 1996 , hlm. 6 .

${ }^{19}$ Pasal 96 huruf b UUPM.

${ }^{20}$ Najib A. Gysmar, op.cit, hlm. 56.

${ }^{21} \mathrm{Ibid}$.

$22 \mathrm{lbid}$. 
menjaga informasi serta rahasia yang dimiliki Wall Street. Pengadilan sependapat dengan' SEC, sehingga tindakan tersebut dikategorikan sebagai insider trading. ${ }^{23}$

Pertanyaan kemudian muncul, apabila kasus serupa terjadi di Indonesia, mampukah UUPM menjangkaunya. Dengan perkataan lain, dapatkah pengadilan menjatuhkan sanksi kepada pelakunya berdasarkan UU Pasar Modal Indonesia tersebut.

Tidak adanya jiwa misappropriation theory dalam Undang-undang Pasar Modal Indonesia merupakan celah hukum yang dapat merugikan investor dalam transaksi efek di bursa efek, yang pada akhirnya dapat menimbulkan ketidakpercayaan masyarakat terhadap bursa efek.

\section{Tidak Adanya Batasan Mengenai Kapan Orang Dalam dapat Melakukan Transaksi Fakta Materiel Terbuka}

Batasan waktu tersebut maksudnya adalah apabila ada suatu fakta materiel yang oleh emiten diinformasikan kepada masyarakat dan setelah fakta materiel tersebut diinformasikan, maka apakah setelah itu orang dalam dapat melakukan transaksi efek atau menunggu sampai waktu tertentu.

Di Amerika Serikat dikenal adanya shortswing profits, yaitu orang dalam perusahaan, pemegang saham $10 \%$ atau lebih dilarang melakukan transaksi efek perusahaannya untuk kepentingan dirinya dalam jangka waktu enam bulan. Apabila hal tersebut terjadi, maka hal itu harus dilaporkan kepada SEC sepuluh hari setelati akhir bulan transaksi tersebut. Ketentuan tersebut dimuat dalam Section 16 (a), 16 (b) Securities Act of $1934 .^{24}$

Ketentuan tersebut hanya mengatur mengenai tidak bolehnya orang dalam melakukan transaksi efek untuk kepentingannya dalam waktu enam bulan, tetapi tidak mengatur mengenai kapan suatu fakta materiel dianggap efektif setelah dibukanya informasi tersebut kepada masyarakat.

Informasi materiel yang dibuka oleh emiten untuk kepentingan masyarakat merupakan dasar bagi investor untuk menentukan kebijakan investasinya apakah akan melakukan transaksi jual atau beli, kebijakan investasi tersebut dapat dilakukan dengan cepat atau lambat.

Cepat atau lambatnya penentuan pilihan transaksi tersebut disebabkan oleh: ${ }^{25}$

1. Tersedianya data yang lengkap mengenai informasi yang dikeluarkan emiten dan keakuratannya;

2. Latar belakang kebijakan emiten dalam melakukan sesuatu yang bersifat materiel tersebut, misalnya akan melakukan akuisisi perusahaan target; dan

3. Kondisi keuangan internal investor ketika informasi materiel dibuka emiten.

Ketiga sebab tersebut dapat menimbulkan sentimen pasar yang pada akhirnya dapat membuat harga efek naik atau turun.

Tidak adanya ketentuan yang jelas mengenai kapan informasi yang dibuka

\footnotetext{
${ }^{23} \mathrm{Ibid}, \mathrm{hlm} .57$.

${ }^{24}$ Ridwan Khairandy dan Najib, op.cit, hlm. 34.

${ }^{25} \mathrm{Ibid}$.
} 
emiten dapat berlaku efektif bagi masyarakat dapat mengakibatkan misleading information yang pada gilirannya akan mengurangi kepercayaan masyarakat terhadap pasar modal.

Prosedur di dalam menemukan indikasi awal adanya insider trading dilakukan dengan cara memantau perkembangan transaksi di bursa. Bilamana ditemukan kecenderungan transaksi yang mencolok, seperti kenaikan atau penurunan harga yang luar biasa, volume dan frekuensi perdagangan yang istimewa (karena saham sebelumnya tidak aktif), termasuk aktivitas transaksi anggota bursa yang luar biasa, maka terhadap transaksi tersebut perlu dilakukan penelitian lebih lanjut. Penelitian pertama yang dilakukan adalah dengan melakukan pengecekan terhadap semua informasi resmi yang telah dipublikasikan, . kemudian emiten juga dihubungi untuk memberikan konfirmasi apakah yang bersangkutan telah memberikan informasi tertentu melalui media massa atau memang ada keadaan/kejadian yang telah terjadi atau akan dilakukan tetapi masih dirahasiakan. ${ }^{26}$

Gejala-gejala di atas perlu diteliti lebih lanjut karena biasanya mereka yang mempunyai informasi orang dalam akan melakukan tindakan jual atau beli mendahului pengumuman kejadian-kejadian penting dalam perusahaan. Mereka yang mengetahui informasi orang dalam biasanya akan lebih dahulu, misalnya kalau ada kenaikan pembagian deviden (dibanding tahun sebelumnya) atau pengambialihan (take over) Emiten karena setelah pengumuman saham biasanya akan mengalami kenaikan. Sebaliknya akan menjual kalau perusahaan akan mengeluarkan pengumuman yang dapat mengakibatkan penurunan harga saham misalnya apabila ada kerugian dalam tahun buku yang bersangkutan."

Apabila tidak ditemukan cukup alasan . yang menunjang adanya indikasi transaksi yang tidak wajar di maksud, maka penelitian berikutnya dilakukan dengan cara memeriksa database anggota bursa maupun emiten yang bersangkutan yang berkaitan dengan kemungkinan hubungan afiliasi satu dengan lainnya. Selanjutnya, perlu dilakukan penelitian terhadap bukti pesanan nasabah yang bersangkutan. Bilamana ditemukan bahwa terdapat hubungan afiliasi antara emiten dengan anggota bursa yang melakukan transaksi atas efek emiten tersebut, atau nasabah dengan orang dalam emiten, maka indikasi memanfaatkan informasi orang dalam kemungkinan telah terjadi. Indikasi seperti ini selanjutnya akan dilaporkan kepada Bapepam dimana sesuai dengan kewenangannya Bapepam dapat melakukan tindak lanjut pemeriksaan maupun penyidikan sesuai UUPM.

\section{Simpulan}

Larangan transaksi efek yang berkaitan dengan insider trading yang dianut UUPM menganut konsep fiduciary duties. Teori ini dalam praktiknya memiliki banyak kelemahan, ia tidak mampu menjangkau penyalahgunaan

${ }^{26}$ Hamud M. Balfas, "Tindak Pidana Pasar Modal dan Pengawasan Perdagangan di Bursa Efek", Jumal Hukum, No. 11 Vol 6, 1999, hlm. 89.

${ }^{27} \mathrm{lbid}, \mathrm{hlm} .93$. 
informasi yang diperoleh oieh orang luar perusahaan secara tidak sengaja atau tidak langsung dari orang dalam.

Dalam kenyataannya, penelusuran atau pembuktian adanya insider trading ternyata bukan suatu hal yang mudah. Kesulitan tersebut antara lain disebabkan oleh lemahnya pengaturan hukum dan tidak adanya batasan mengenai kapan orang dalam dapat melakukan fakta meteriil terbuka.

\section{Daftar Pustaka}

Balfas, Hamud M. "Tindak Pidana Pasar Modal dan Pengawasan Perdagangan di Bursa Efek", Jumal Hukum, No. 11 Vol 6, 1999.

Fuady, Munir. Pasar Modal Modem. Bandung: Citra Aditya Bakti, 1996.
Gysmar, Najib A. Insider trading dalam Transaksi Efek. Bandung: Citra Aditya Bakti, 1999.

Jalil, A. Sofyan. "Manifulation dan Insider trading", makalah di Pendidikan dan Pelatihan bagi Profesi Penunjang Konsultan Hukum Pasar Modai Angkatan VII, LMKA - BPLK, Jakarta 21 Oktober - 8 November 1996.

Khairandy, Ridwan dan Najib."Aspek Hukum insider trading di Bursa Efek", Media Advokat, Edisi Perdana, 1997.

Nasution, Bismar. Keterbukaan dalam Pasar Modal. Jakarta: Program Pascasarjana Fakultas Hukum Universitas Indonesia, 2001.

Safitri, Indra. Transparansi Independensi, dan Kejahatan Pasar Modal. Jakarta: Go Global Book, 1998. 